\title{
Dynamics of the Intellectual Tradition of Ulama Dayah Aceh
}

\section{Syadidul Kahar}

STIT Babussalam Aceh Tenggara, Indonesia

Email:syadidulk@yahoo.com

\section{Abstract:}

This research provides information about the intellectual dynamics of dayah ulama Aceh. The goal is to find a common thread between tradition and modernization in dayah ulama Aceh scholarship. This research is a historical research using a social history approach. Based on the results of data analysis, the research results show that the role of the dayah is a realization of the intellectual manifestation of the dayah ulama Aceh. Dayah is used as a forum to teach various knowledge of Islamic teachings with a curriculum based on classical books or turats by maintaining the faith of experts in the sunnah wal jamaah. Based on the historical dynamic journey, dayah still exists as a fortress and a place for cadre generations to understand the teachings of Islam. So, Acehnese dayah intellectuals emphasize more on understanding classical books with actual contexts. So, the demands of the changing times provide its own dynamics to the intellectuals of the dayah ulama Aceh, but in this case the emphasis is that Islamic teachings through dayah continue to exist.

Keywords:

intellectual tradition; ulama dayah; Aceh

\section{Introduction}

The development of Islam in the archipelago is basically very attached to the central role of the ulama, the ulama who are most instrumental in introducing Islam to the people of the archipelago and Aceh in particular, which is the main gate for the entry of Islam in this archipelago. The scholars carried out various aspects in broadcasting Islam and emphasized more on aspects of cultural and educational approaches. Seeing this central role, the ulama are as community elites who have such a big influence on the social life of society with responsibility for religious values. The critical thinking of the scholars has given birth to a dynamic culture and shapes the color of religious life in society through the transmission of knowledge with Islamic values itself.

Education is an obligation of every human being that must be pursued to hold responsibilities and try to produce progress in knowledge and experience for the lives of every individual. Indonesia is a developing country that also prioritizes and tries to develop all aspects of the education world. This research focused on the study of character education values contained in the animation movie of nussa and rarra. Character education values can be said to be a program to form attitudes that connect or harmonize between culture, environment, and social.

Based on social reviews, Ulama are community figures who become taladan because of their practice of religious knowledge. The success of the ulama when he became the leader of the community, made the ulama influential in terms of politics so that his influence could move the emotional sympathizers of his followers. If we pay attention lately, there are more and more ulama figures involved in practical politics. If an element of society enters the political arena, it will think of a strategy to win the votes of the people. With this problem, a 


\section{Lakhomi Journal: Scientific Journal of Culture \\ ISSN: 2774-311X (Online), 2774-4728 (Print)}

\section{Vol. 2, No. 1, March 2021, Page: 46-53 \\ Email: lakhomijournal@gmail.com}

phenomenon about religion for politics will emerge or vice versa. So in this paper will discuss the extent to which the role of the ulama in politics or what political concepts are offered by the ulama in fighting for the aspirations of society.

The thoughts of the ulama are poured out in a container called education, through this the generations of Islam are educated to have the teachings of Islam as a relay of Islamic symbols. Based on the dynamics of the historical journey of the role of the ulama in cadre of the Islamic generation, the development of the Islamic thought tradition has changed by forming two conditions, namely the intellectual tradition that developed before coming into contact with the notion of renewal and of thinking that developed after being exposed to a touch of modernism.

Dayah is the name of the Acehnese for Islamic boarding schools. The word dayah itself comes from Zawiyah Arabic which literally means corners. Pojokan Nabawi mosque where the Prophet used to convey religious advice to friends. Furthermore, the word zawiyah becomes a dayah due to the strong Arab influence in Aceh (Amiruddin, 2010; Ali Hasjmy, 1978; Ismuha, 1996). In Java the term "dayah" is not known, which is known only as Islamic boarding school. (Mizaj, 2018)

In Aceh itself, the intellectual tradition of the ulama through an educational forum with a dynamic touch of renewal gave birth to three types of dayah (Acehnese traditional Islamic educational institutions), namely Dayah Salafi, Integrated Dayah and Ulumul Quran dayah. Based on this, it cannot be denied thatprogress of a nation and society can not be separated from setting history of a civilization, the legacy of the past that has been achieved by previous generations, so that it becomes a benchmark for moving forward for the next generation. This fact is beyond doubt, that the advancement of past Aceh civilization is closely related to the scientific and intellectual traditions of the ulamadayah Aceh at that time. The scientific and intellectual traditions of dayah scholars in the course of their history in an effort to inherit teachings and values carried out by ulamadayah besides through Islamic education institutions, also through their pens (works).

The scholarship of the dayah scholars in the past is historical evidence that the scientific aspects, competences and intellectual traditions can be seen with the existence of traditional dayahs with curricula and systems that still survive the previous dayah ulama system. This can be seen with the advancement of dayahs with traditional bases such as Dayah Darussalam Labuhan Haji South Aceh, Dayah Darul Ihsan Labuhan Haji South Aceh, Dayah Al Madinatud Diniyah Babusslam Blang Bladeh, Dayah Malikussaleh Panton Labu North Aceh, Dayah Darul Huda Lhueng Angen, Lhok Nibong, Dayah Darul Munawwarah Kuta Krueng and many more traditional Acehnese dayahs that still exist today. Based on the description of these explanations, this research focuses on examining the intellectual traditions of the Aceh dayah ulama.

\section{Research Methods}

This research is a historical research, explaining that history is concerned with process. Research on the intellectual tradition of dayah ulama is more directed at the process so that the object of study in this article can be seen how it was formed and how the intellectual development of the dayah ulama was also. This research uses historical or historical research methods, which is an attempt to provide an interpretation of the up and down trend part of the state of the past to obtain a generalization that is useful for understanding historical reality, comparing with the present situation and can predict the situation that will be. come. The 
historical method is to critically analyze historical sources (written or otherwise) and write down the results based on the facts that have been obtained, hereinafter referred to as historiography. Historiography is the last series of historical research processes starting from heuristics, criticism and interpretation in order to establish interrelated meanings, all of which are presented in the form of historiography. The approach used in this research method is to use a social history approach.

There are four data collection techniques used in this research, namely documentation study, observation, literature search, and interview. Historical sources are also called historical data, the data collected must be in accordance with the type of history to be written. In terms of material, data sources can be divided into two, namely written and unwritten, or documents and artifacts. Meanwhile, according to the delivery, the source can be divided into primary and secondary sources. Historical sources can be said to be primary sources if they are presented by eye witnesses, while secondary sources are data submitted by non-eye witnesses. The data sources in this study are historical sources and developments and intellectual traditions of dayah scholars in Aceh.

The historical method is a specific indication of the material, criticism, interpretation, and presentation of history, meaning that the historical method is a way of knowing history. From this definition, it can be seen that the historical method is a method used in the research process of past sources which is done critically-analytically and systematically which is presented in writing. So in this case, the analysis in this study was carried out from the beginning of the study to the end of writing history.

\section{Results and Discussion}

\subsection{The Intellectual Realization of Aceh Dayah Ulama through Dayah Curriculum}

Basically the traditional Aceh dayah curriculum does not have a standard rule for the various materials taught. This means that almost all dayahs in Aceh do not have a curriculum which is the central provision that becomes the reference and benchmark for all dayah education institutions in Aceh. The curriculum developed in dayah only depends on the wishes and abilities of the leaders. But what is unique here is that in general there are similarities in all dayahs regarding the main subjects taught to the Talibs. Among them are knowledge of Islamic law (Fiqh Science), grammar (Nahwu Science and Neuroscience), Tawhid and Tafsir. For Fiqh Science subjects, the average dayah currently teaches the following books:
a. The book of Matn al-Taqrib by Abi Syuja
b. Kitab al-Bajuri al-Syarah Matn al-Taqrib written by Shaykh Ibn Qasim
c. Fath al-Wahab, written by Shaykh Sulaiman Al-bujairimi died;
d. Kitab al-Mahalli by Sheikh Djalaluddin Almahalli
e. The book of Tuhfatul Muhtaj written by Sheikh Ibn Hajar Al Haitami,

In the field of neuroscience, the books taught include the following:
a. The book of Dammun wa al-Madkhal
b. Kitab al-Kailani
c. Kitab al-Matlub,

In Nahwu Science, the subjects taught include the following:
a. the book of Matn al-Jarumiyah
b. Kitab al-Kawakib
c. Kitab al-Khudari. 
In the Quranic Tafsir lesson the manual is as follows,
a. Jalalain's interpretation
b. Khazain's interpretation
c. Tafseer of Ibn Kathir
d. Tafseer of Ibn Abbas and others.

In the Hadith lessons, what is taught is as follows:
a. Matan Arba'in
b. the book of Majali al-Sanniyah,
c. the book of Abi Jamarah
d. the book of Fath al-Mubdi and others

These books are common books taught in Dayah Acehm but in some Aceh dayah there are many more books being taught and of course the development of these books. Based on this explanation, it provides an illustration that dayah ulama in Aceh have an intellectual tradition by understanding the classical books of the ulama which have become the agreement of Acehnese scholars in understanding Islamic teachings and are taught to the next generation. The purpose of the agreement here is as previously described about the books taught which are in line with the creed of the expert on sunnah wal jamaah.

The dayah education curriculum includes several components, including the objectives of the content of knowledge and learning experiences, strategies and evaluation. But in its implementation, it still uses traditional concepts. The content component includes the achievement of clear targets, standard material for Thalib learning outcomes and procedures for implementing personality learning. The strategy component is illustrated by the method taken in implementing the teaching method in assessing how to carry out guidance and counseling and how to organize dayah activities as a whole. The way of carrying out teaching includes the applicable way of presenting each field of study including the way of teaching and the learning tools used.

\subsection{The Intellectual Tradition of Abuya Muhammad Waly Al Khalidy}

The specialization of the intellectual tradition of Abuya Muhammad Waly Al Khalidi does not deny the thoughts of other dayah scholars. The specialization in this matter is to provide an overview of the intellectual traditions of other dayah scholars. as previously mentioned, the Aceh dayah curriculum has similarities, even though the ulama have different intellectual backgrounds. Dayah Darussalam Labuhan Haji, which is led by Abuya Muhammad Waly Al Khalidi, has been touched by reforms whose emphasis is in the form of curriculum and classical systems.

Most of the dayahs in Aceh are networks of Dayah Darussalam Labuhan Haji, the network of students is spread not only in the area, but also to several areas in Aceh, such as East Aceh, North Aceh, Aceh Jeumpa, West Aceh, Aceh Singkil, North Sumatra, West Sumatra and even to Malaysia. This dayah gave birth to many scholars including Teungku Adnan Mahmud from Bakongan, South Aceh, Teungku Muhammad Daud Zamzami from Aceh Besar, Teungku Abdul Aziz Saleh Mesjid from Raya Samalangga, North Aceh, and Teungku Muhammad Amin (Tu Min) from Blang Bladeh, Bireun, and other scholars in Aceh. So it is very natural that he was awarded the father of Aceh Education by the governor of Aceh Irwandi Yusuf on September 2, 2008. This is one of the reasons that intellectual Abuya Muhammad Waly Al Khalidi can describe the intellectual traditions of the Acehnese Dayah scholars. 
Historically, in 1917 in Blang Poroh village, Labuhan Haji district, South Aceh, Sheikh Muda Waly Al khalidy was born. He is the youngest son of Sheikh H. Muhammad Salim bin Malin Palito who came from Batu Sangkar, West Sumatra. The basic education of Shaykh Muda Waly's Islamic teachings was obtained from his parents who were preachers at Labuhan Haji. He received basic knowledge such as the $\mathrm{Al}$ Quran and small books on tawhid, fiqh, and the basic knowledge of Arabic from his father and he also entered the Volks School, an educational institution owned by the Netherlands. This school education was carried out in line with learning religious knowledge which was pursued from his parents. So, Abuya Sheikh Muda Waly received two education, namely religious education and general education. After he finished his education at the Volks School, He continued his education to his father who was in the capital city of Labuhan Haji, led by Teungku Muhammad Ali, namely the dayah Jam iah Al Khairiyah. Teungku Muhammad Ali for the people of South Aceh at that time was better known as Teungku Lampisang, he came from Aceh Besar.

Abuya Muda Waly studied at Dayah Al Khairiah for about 4 years. He continued his knowledge journey at Dayah Bustanul Huda in the capital of Blang Pidie sub-district. This dayah was led by Sheikh Mahmud. In the Dayah Bustanul Huda Abuya Muda Waly was forged with systematic Islamic scholarship on books that were famous among Syafi iyah scholars. The sciences obtained from the books of I anatut Thalibin, Tahrir, and Mahally in fiqh, Alfiyah and Ibn 'Aqil are in the science of nahwu and sharaf. Furthermore, he continued his scientific journey in Banda Aceh, not long after he participated in studying for less than one Dayah day at Krueng Kale led by Sheikh H. Hasan Krueng Kale, because what was taught in the dayah was still in the context of his knowledge which was obtained from the dayah Babul Huda, he continued his scientific journey to Dayah Indrapuri led by Sheikh Hasballah Indrapuri. The science that stands out in this dayah is the field of knowledge of the Koran, including in this regard with qiraat. Dayah Indrapuri is familiar with modern concepts, the learning system uses benches.

During his study in Banda Aceh, he received an offer from Teuku Hasan Glumpang umbrella who was one of the community leaders to study at a college in Padang. The educational institution is the Normal Islam School which is a modern educational institution that has a name in West Sumatra, the founder of this institution is Mahmud Yunus who is an alumni of Al Azhar Cairo. He had studied at the Normal Islam School for about three months, according to him the curriculum he had studied in his religious education was not in depth and sufficient, so he finally resigned with respect. He made this decision because basically his goal of continuing his education in various Islamic educational institutions was to deepen the knowledge of religion. In fact, according to him, at the Normal Islam School, very little religion is taught in normal Islam. This is natural because in these educational institutions that have undergone modernization, general subjects are taught more than religious lessons.

Abuya Sheikh Young Waly also obtained religious knowledge from the scholars of Mecca and Medina when he carried out the pilgrimage in 1939. As for the teachers he received from the religious sciences was Sheikh Ali Al Maliki, in that scholar he received a certificate of the books. hadith from Shaykh Ali Al Maliki. While in Makkah Sheikh Muda Waly was in the same age as Sheikh Yasin Al Fadani who led the Darul Ulum Education Institute in Makkah. He often discussed with scholars while in Medina, including scholars who came from other countries, especially from Egypt. To perfect his knowledge, Sheikh Young Waly took the Naqsyabandiyah Order to a great Tariqah Ulama in West Sumatra, namely Sheikh Abdul Ghaniy Al Kamfary at Batu Bersurat, Kampar, Bangkinang. 
At the end of 1939 he founded Dayah in Blang Poroh Darussalam Labuhan Haji, South Aceh. In the dayah he built, Sheikh Muda Waly taught apart from the students who stayed in the dayah, Abuya also taught knowledge to the public and he also developed and taught the Naqsyabandiyah Order which was certified by Sheikh Abdul Ghaniy Al Kamfary. Based on his educational background, both in terms of religion and general education, it affects the dayah education students he forms. Based on his scientific odyssey, he formed a modern-based education system, there are two concepts that are applied in the education system in dayah namely First, the qadim system, This system still adheres to the classical or traditional system in Aceh, which emphasizes that the books being studied must be understood using the serogan or wetonan method. Second, the madrasah system, this system students are familiar with the classical system by using a bench and a blackboard which emphasizes multiplying the discussion to deepen a subject not in the khatam book or the qadim system. It seems that these two systems are very interesting so that many students who come to Darussalam come from various regions.

Based on the scientific literature of Acehnese scholars and Islamic boarding schools in Aceh, they almost have a scientific pedigree with Abuya Muda Waly. Among the scholars are as follows:

1. Abon Abdul Aziz who is the leader of the LPI Dayah. MUDI MESRA Samalanga, now this dayah is led by his son-in-law who is an alumnus of MUDI MESRA Samalang Dayah, namely Abu H. Hasanoel Basry. Based on literature obtained from the secretariat of the Al Aziziyah Samalanga Islamic Education Foundation, the current branch of MUDI MESRA Samalanga Dayah is 594.

2. Abu Tu Min (H. Muhammad Amin), is the leader of Dayah Al Madinatud Diniyah Babusslam Blang Bladeh, Bireun dayah.

3. Abu H. Ibrahim Bardan, who is the leader of Dayah Malikussaleh Panton Labu in northern Aceh. He is an alumnus of the Dayah MUDI MESRA Samalanga student of Abu Abdul Aziz.

4. Abu Daud Lhoknibong led by Dayah Darul Huda Lhueng Angen, Lhok Nibong, North Aceh. He is an alumnus of Dayah MUDI MESRA Samalanga, a student of Syekh Abdul Aziz.

5. Tgk. H Usman Kuta Krueng student of Abu Abdul Aziz Dayah MUDI MESRA Samalanga, Beliu is the leader of Dayah Darul Munawwarah, Kuta Krueng, Bandar Dua. Pidie is glorious.

6. Abu Abdulah Hanafiah (Abu Tanah Mirah), the leader of Dayah Darul Ulum, Tanoh Mirah. Bireun. He is a student of Sheikh Muda waly.

7. Abu Mustafa Puteh or known as Abu Paloh Gadeng, he was a student of Abu Muhammad Amin Blang Bladeh. He is the leader of the Dayah Darul Huda, Paloh Gadeng Aceh Utara.

8. Abu Marhaban Adnan led by Dayah Ashhabul Yamin, Bakongan, South Aceh. He is a student of Sheikh Abdul Aziz and son of Syekh Adnan Mahmud Bakongan.

9. Abuya Muhammad Nasir, he is the son of Abuya Muda Waly. He is the leader of Dayah Serambi Mekah, he is also a student of Sheikh Abdul Aziz, Samalanga.

10.Abu Asnawi Ramli who is the leader of Dayah Bahrul Ulum Diniyah Islamiyah (BUDI) Lamno, Aceh Jaya. Previously led by Tgk. Sheikh Ibrahim Lamno, a student of Syekh Abdul Aziz Samalanga.

11.Dayah Ulee Titi, Ulee Titi, Aceh Besar, led by Tgk. Shaykh 'Athaillah (student of Syekh Ibrahim Lamno), and many other dayahs whose knowledge is from Abuya Muda Waly Al Khalidi.

These dayahs and many other dayahs constitute dayahs that have scientific ties with Sheikh Muda Waly. He is a scholar who is very instrumental in defending the Ahlussunnah and Syafii schools of thought in Aceh. His wisdom and knowledge in explaining and giving birth to laws based on the ushulfigh istimbat method can be said to be Mujaddid for Aceh and its surroundings. These alumni from Darussalam Labuha Haji are also not only in Aceh but outside 
Aceh, such as in West Sumatra, North Sumatra, Sulawesi and in other areas. Among his sons who are active at the national and international levels are Prof. DR. Abuya Muhibuddin Waly, he is a lecturer at UIN Syarif Hidatullah, and other Islamic universities both in Indonesia and abroad. He also played a role in government both at the national and provincial levels of Aceh. Next up is Abuya Amran Waly Al Khalidy, he is the head of the center of the Southeast Asia Tawheed Research Council (MPTT). This organization has conducted international seminars both in Indonesia and abroad and has been attended by 14 countries

\subsection{Dayah of Ma'had Al Ulum Diniyyah Islamiyan Becomes Raya (MUDI MESRA) Samalanga: Traditional of Dayah Ulama Intellectual Modernization}

This chapter needs to be explained to support the traditional intellectual strengthening of dayah ulama. Basically dayah ulama are identical to their traditional thoughts, the birth of the idea of dayah education by Abuya Muhammad Waly Al Khalidi gave its own color to the dayah education system. Dayah Mudi Mesra Samalanga is the same as it is, to respond to the changing times in modern life, the MUDI MESRA Samalanga dayah continues to make improvements so that it is able to make the traditional dayah into an educational institution that is worthy and accepted in various circles. So the reforms carried out by dayah Mudi Mesra did not destroy the traditional order of the dayah itself, but tried to make the dayah continue to exist with the demands of the times.

Various facilities and facilities continue to be improved, ranging from school buildings, dormitories, cooperatives, canteens, to the provision of sports facilities for students and teachers. Based on this policy, it is not surprising that the MUDI dayah has given birth to alumni who have established dayahs in various places. Based on the data obtained, the number of dayahs registered with Mudi's dayah is 594, even outside Aceh, such as Medan, Jambi and Malaysia.

Even though the dayah is following the times, the dayah is still strong with the initial ideals of the dayah establishment. For example, with the existence of ICT in dayah, Dayah MUDI MESRA Samalanga uses ICT to further develop da'wah but on the other hand, because there are no limitations to the existence of ICT, the power to face the challenges of globalization in controlling the morals of the people is increasingly complex. This complexity can be seen from the various internal problems of education in MUDI MESRA Samalanga Dayah which also faces obstacles in the context of the transformation and transmission of knowledge in the midst of a changing society. From a social perspective, Dayah MUDI MESRA Samalanga is a forum for religious and moral values of the people as a place of protection and preservation. Various problems of the people, both mental aridity, spiritual turmoil, restlessness.

Apart from the 'pros and cons of the impact of ICT, but this is a support for it Dayah MUDI MESRA in developing dakwah space and developed at the Mudi missionary development institute (LPDM). Then the wiggle room fromLajnah Development of Da'wah Mudi (LPDM) in the field of preaching and publication. The realization of these factors has made YPIA Samalangan manages two official websites, namely www.mudimesra.com and www.umdah.co.id. Another MUDI dayah official website, www.lbm.mudimesra.com is managed by LBM MUDI. UMDAH, which is the official MUDI dayah magazine The aim of the ICT is to publish religious knowledge through various print and electronic media. Therefore, based on these reviews, the role of ICT is very supportive of the vision and mission of the dayah, including through recitations broadcast via live streaming via www. Radio. Mudimesra.com, Mudi TV so that it can be heard on a wide scale even abroad. 
Basically, the main goal in dayah education is a religious factor, the goal is to defend ahlu as sunnah wa al jamaah from ideas that destroy religion. The population of Aceh is predominantly Muslim, of course this makes it easier for Islamic educational institutions to develop and advance in giving birth to a quality generation. Every dayah policy certainly easily gets support from the community. It has been explained previously that Aceh's social life is inseparable from religious values. Especially for the people of Aceh, religion is a part of life that acts as a unifying tool, in the conditions and situations faced by the community, religion is also a reference for the community to find solutions. From a sociological perspective, religion is a social category, From the explanation above, religion is theoretically built with a system that has the power to bind society to build social and religious ties to society. So the implementation of religion in society is able to order spiritual values on the basis of organized psycho-religious ties. This is what forms the social system of the Acehnese people, for the Acehnese religion builds an order of community life that has constructive and regulative power. This is where the main role of the intellectual tradition of dayah Acehnese scholars is to maintain Islamic teachings by providing education to dayah santri.

\section{Conclusion}

Basically the role of the dayah is a realization of the intellectual manifestation of the Aceh dayah ulama. Dayah is used as a forum to teach various knowledge of Islamic teachings with a curriculum based on classical books or turats by maintaining the faith of experts in the sunnah wal jamaah. Based on the historical dynamic journey, dayah still exists as a fortress and a place for cadre generations to understand the teachings of Islam. So, intellectual dayah Acehnese scholars emphasize more on understanding classical books with actual contexts. So, the demands of the changing times provide its own dynamics to the intellectuals of Acehnese dayah scholars, but in this case the emphasis is on Islamic teachings through dayahs to continue to exist.

\section{References}

Ahmad Syafe'i (ed.). (1999). Research on Religion Development towards the Beginning of Millennium 3, cet. 1, Jakarta: Religious Research and Development Agency.

Diauddin. (2020). Learning Management at Dayah Darussa'adah Teupin Raya, Dissertation, Postgraduate UIN North Sumatra.

Erawadi. (2009). Traditions, Discourse and Islamic Intellectual Dynamics of Aceh in the XVIII and XIX centuries, Jakarta: Balitbang Ministry of Religion.

Kuntowijoyo. (2013). Introduction to History, cet. 1, Yogyakarta: Tiara Wacana Publisher.

Mizaj. (2018). Dayah Darussalam Network and Dayah Awakening in Aceh. Budapest International Research and Critics Institute-Journal (BIRCI-Journal). P. 13-22

Notosusanto, Nugroho. (1978). Contemporary History Research Problems: An Experience, Jakarta: Idayu Foundation.

Writer team. (2018). Brief Profile of the Al Aziziyah Samalanga Education Foundation, Samalanga.

Waly, Muhibuddin. (2016). Our Father Maulana Syeikh Haji Muhammad Waly Al Khalidy: Teungku Syeikh Haji Muda Waly, Banda Aceh: Al Waliyah Publising. 